Article

\title{
Evaluation of Fresh Azolla pinnata as a Low-Cost Supplemental Feed for Thai Silver Barb Barbonymus gonionotus
}

\author{
Mousumi Das * (D), Ferdous Ibn Rahim and Md. Amzad Hossain \\ Department of Aquaculture, Faculty of Fisheries, Bangabandhu Sheikh Mujibur Rahman Agricultural \\ University, Gazipur-1706, Bangladesh; ferdousirp@gmail.com (F.I.R.); amzad@bsmrau.edu.bd (M.A.H.) \\ * Correspondence: mousumi.aqc@bsmrau.edu.bd; Tel.: +88-02-920-5310-14 (ext. 2487)
}

Received: 30 December 2017; Accepted: 28 February 2018; Published: 5 March 2018

\begin{abstract}
Aquatic fern Azolla pinnata comprises significant high food value with a good proportion of protein, vitamins, and minerals. This study was carried out to examine the effect of fresh A. pinnata as a substitution of commercial fish feed (CFF) for Thai silver barb Barbonymus gonionotus. Post fingerlings of $B$. gonionotus were reared in five treatments, labeled $\mathrm{T}_{1}$ to $\mathrm{T}_{5}$, by substituting $0 \%, 25 \%, 50 \%, 75 \%$, and $100 \%$ protein of CFF with A. pinnata protein (dry matter basis) respectively for 56 days. The specific growth rate, net production rate, protein efficiency ratio, proximate composition, and overall conditions of fish were not significantly varied between the fish reared completely with CFF and $25 \%$ substitution with $A$. pinnata. However, a significantly higher profit rate (431.49 USD ha ${ }^{-1} 56$ day $^{-1}$ ) was calculated for fish reared in $T_{2}$ than other treatments. In contrast, there was a significant reduction of growth and other parameters of the fish that were observed in the case where more than $25 \%$ CFF was substituted with $A$. pinnata. The poorest performance was observed in fish fed completely with $A$. pinnata, at $\mathrm{T}_{5}$. Based on the results, $25 \%$ of CFF of Thai silver barb could be substituted with fresh $A$. pinnata without significantly lowering their growth and product quality and could contribute significant to a higher profit margin.
\end{abstract}

Keywords: Thai silver barb; fresh Azolla pinnata; commercial fish feed substitution; growth; profit

\section{Introduction}

For intensive aquaculture operation, high-quality protein-rich feed is very important to ensure higher production rates [1,2]. The feed must be well balanced with all the necessary nutritional contents. The feed used in aquaculture is quite expensive, irregular, and short in supply in many third world countries. Fish feed constitutes a major portion of the production cost in intensive and semi-intensive aquaculture practice. A careful selection of feed ingredients for use in aquafeed will play a vital role in the nutritional and economic success of farmed fish. Fish meal is a good source of quality protein and an increasingly expensive component of commercial fish farming. The price of fishmeal has increased significantly since 2006 [3]. Consequently, such high costs often increase the cost of production, reducing the profit margin and increasing the consumers' price. The ever-increasing cost of fish feed has engendered research interests into ways of replacing it totally or partially with other less-expensive protein diets of comparable feed ingredients $[3,4]$. There is a need for a research effort to evaluate the nutritive value of different non-conventional feed resources, including terrestrial and aquatic macrophytes [1]. Therefore, the major prerequisite for profitable fish farming is the availability of suitable feeds, formulated from locally-available cheap ingredients that will supply adequate nutritional requirements for the cultured fish $[5,6]$.

Thai silver barb Barbonymus gonionotus, an exotic fish of Bangladesh belonging to the family Cyprinidae, could be a suitable species for aquaculture due to its good palatability, high yield potential, 
and very large market demand $[7,8]$. Being an omnivorous species in origin, it prefers a feed of aquatic plants, soft grasses, and planktons. It responds well to a wide range of culture conditions with comparatively low-cost, simple management practices [9]. It grows quickly at high stocking densities and is quite suitable for polyculture [10]. It occupied a remarkable position in the aquaculture scenario of Bangladesh within a short time after introduction. Commercial production of B. gonionotus has been facing great economic challenges in Bangladesh due to the sharp rise of feed prices. The high cost of commercial feed is limiting the potential development of intensive farming of that species.

The aquatic free-floating fern Azolla pinnata belongs to the family Azollaceae, which grows in association with the blue-green algae, Anabaena azollae, and is considered to be a promising feed because of its good nutritive value, the ease of cultivation, and high productivity [11,12]. A. pinnata appears as a good source of protein and contains almost all essential amino acids that are superior to wheat bran, maize, offals, etc. [13,14]. Generally, the crude protein content of that plant species is found in the range from $25 \%$ to $30 \%$ in dry matter basis at optimum growth conditions [14]. Under natural conditions, protein values near $20 \%$ to $22 \%$ are frequent. Therefore, the protein content of A. pinnata is comparable or higher than that of most other aquatic macrophytes. This plant is naturally rich in minerals such as iron, calcium, magnesium, potassium, phosphorus, manganese, etc., apart from appreciable quantities of vitamin $\mathrm{A}$, precursor beta-carotene, and vitamin $\mathrm{B}_{12}$ [15]. It is also found that Azolla plants contain some probiotics and biopolymers [16].

Azolla pinnata is common in most Asian rice fields, ponds, and roadside ditches, and has considerable potential in fish culture, especially in the rice-fish system. It proliferates at a high rate in natural ponds and, if necessary, for large supply, can be grown with very low cost [14]. Increased fish production has been demonstrated in integrated rice-fish, Azolla production systems where the plant served as an in situ fresh food for the macro phytophagous fish [17]. It has attracted attention as a nitrogenous fertilizer and as a source of dietary nitrogen for herbivorous fish and livestock. Azolla pinnata as a fresh feed, in combination with a food level of natural feeding, can be beneficial to fish production [18]. Therefore, it could be an excellent inexpensive feed for B. gonionotus. Dried and processed Azolla have been tested as feed ingredient in a number of fish species (e.g., tilapia, carp, etc.) for their effect on growth and yield $[19,20]$. However, its acceptability in the fresh or unprocessed form as a supplementation of commercial fish feed (CFF) has not been contemplated for the silver barb. Feeding A. pinnata in its fresh form could reduce the cost of feed immensely and would be very convenient and farmer-friendly if its application can be established.

The aim of this experiment was to examine the growth, feed utilization, and net profit margin of Thai silver barb B. gonionotus fed with substituting different levels of CFF with fresh A. pinnata.

\section{Results}

Proximate composition and minerals content of the floating CFF and cultured A. pinnata in this study are shown in Table 1. A significant higher content of water, ash, and lower content of protein was found in A. pinnata compared to the CFF $(p<0.05)$. The lipid content of the plant was not significantly different from CFF $(p>0.05)$. Azolla pinnata was found to be rich in minerals. All of the tested micro-minerals ( $\mathrm{Fe}, \mathrm{Zn}, \mathrm{Cu}$, and $\mathrm{Mn})$ and $\mathrm{Ca}$ content was significantly higher $(p<0.05)$ in A. pinnata while the other macro-minerals were similar, except for a lower content of $\mathrm{P}$ compared to the contents found in floating CFF.

Over the experimental period, the water quality parameters of the pond were within the recommended range for the experimental fish. The water average temperature ranged from $30.3 \pm 0.25$ to $31.7 \pm 0.21{ }^{\circ} \mathrm{C}, \mathrm{pH}$ from $7.40 \pm 0.10$ to $7.61 \pm 0.06$, dissolved oxygen (DO) from $6.12 \pm 0.10$ to $6.23 \pm 0.06$ parts per million (ppm), ammonia from $0.28 \pm 0.05$ to $0.38 \pm 0.12 \mathrm{ppm}$, nitrate-nitrogen from $0.06 \pm 0.01$ to $0.09 \pm 0.01 \mathrm{ppm}$, and phosphate-phosphorus from $0.84 \pm 0.16$ to $0.92 \pm 0.25 \mathrm{ppm}$. 
Table 1. Proximate composition (\% in dry weight) and minerals content of the floating commercial fish feed and fresh Azolla pinnata.

\begin{tabular}{ccc}
\hline Composition (\%) & Floating Commercial Fish Feed (CFF) & A. pinnata \\
\hline Moisture & $11.50 \pm 0.20^{\mathrm{a}}$ & $67 \pm 1.44^{\mathrm{b}}$ \\
Crude Protein & $35.0 \pm 0.46^{\mathrm{a}}$ & $27.0 \pm 0.39^{\mathrm{b}}$ \\
Crude Lipid & $3.0 \pm 0.27^{\mathrm{a}}$ & $2.65 \pm 0.10^{\mathrm{a}}$ \\
Ash & $10.0 \pm 0.22^{\mathrm{a}}$ & $17.37 \pm 0.73^{\mathrm{b}}$ \\
\hline Minerals (\%) & & \\
\hline $\mathrm{Ca}$ & $0.10 \pm 0.015^{\mathrm{a}}$ & $0.71 \pm 0.038^{\mathrm{b}}$ \\
$\mathrm{Mg}$ & $0.053 \pm 0.01^{\mathrm{a}}$ & $0.060 \pm 0.004^{\mathrm{a}}$ \\
$\mathrm{K}$ & $0.18 \pm 0.02^{\mathrm{a}}$ & $0.16 \pm 0.03^{\mathrm{a}}$ \\
$\mathrm{P}$ & $0.70 \pm 0.055^{\mathrm{a}}$ & $0.20 \pm 0.047^{\mathrm{b}}$ \\
$\mathrm{S}$ & $0.17 \pm 0.03^{\mathrm{a}}$ & $0.13 \pm 0.028^{\mathrm{a}}$ \\
$\mathrm{Na}$ & $0.081 \pm 0.005^{\mathrm{a}}$ & \\
\hline Minerals (ppm) & & $0.083 \pm 0.004^{\mathrm{a}}$ \\
\hline $\mathrm{Fe}$ & $0.07 \pm 0.003^{\mathrm{a}}$ & \\
Zn & $88 \pm 0.45^{\mathrm{a}}$ & $280 \pm 0.026^{\mathrm{b}}$ \\
$\mathrm{Cu}$ & $17 \pm 0.32^{\mathrm{a}}$ & $28 \pm 0.60^{\mathrm{b}}$ \\
$\mathrm{Mn}$ & $54 \pm 0.17^{\mathrm{a}}$ & $576 \pm 1.10^{\mathrm{b}}$ \\
\hline
\end{tabular}

Values expressed as mean \pm standard deviation (SD) $(n=3)$. Means with different superscripts $(\mathrm{a}$ and $\mathrm{b})$ are significantly different $(p<0.05)$. ppm: = Parts per million.

Though B. gonionotus consumed fresh A. pinnata efficiently, the fish preferred CFF than Azolla as observed visually during feeding. However, in the case of $100 \%$ feeding with $A$. pinnata $\left(\mathrm{T}_{5}\right)$ fish consumed around $15-20 \%$ fresh plant at the time when provided, but they took all the plants gradually before serving the next meal. Growth and production performance of fish using floating pellet feed and A. pinnata after 56 days are summarized in Table 2. The highest average weight gain (AWG) $(27.03 \pm 0.16 \mathrm{~g})$, specific growth rate (SGR) $\left(3.70 \pm 0.14 \%\right.$ day $\left.^{-1}\right)$, and net production rate (NPR) $\left(9.88 \pm 0.65\right.$ ton ha ${ }^{-1}$ year ${ }^{-1}$ ) were observed in fish fed at $\mathrm{T}_{1}$ entirely with CFF. However, there was no statistical difference of AWG, SGR, and NPR of fish fed with the $25 \%$ substitution of A. pinnata protein in $\mathrm{T}_{2}$ than in $\mathrm{T}_{1}(p>0.05)$. The AWG, SGR, and NPR of fish reduced significantly from $50 \%$ to $100 \%$ Azolla protein substituted diet $\left(\mathrm{T}_{3}, \mathrm{~T}_{4}\right.$, and $\left.\mathrm{T}_{5}\right)(p<0.05)$. The growth and production performance of fish gradually decreased with the increase in the levels of supplementary $A$. pinnata. The lowest SGR $\left(2.43 \pm 0.18 \%\right.$ day $\left.^{-1}\right)$ and NPR $\left(4.85 \pm 0.79\right.$ ton $^{-1}{ }^{-1} \cdot$ year $\left.^{-1}\right)$ were found from the fish fed completely with plant protein $\left(\mathrm{T}_{5}\right)$. Therefore, a negative effect in terms of growth was seen in fish when more than $25 \%$ protein of CFF was replaced with $A$. pinnata protein.

The condition factor $(\mathrm{CF})$ of the fish was lowest $(1.59 \pm 0.095)$ for fish fed with $0 \% \mathrm{CFF}\left(\mathrm{T}_{5}\right)$ which varied significantly from the fish fed the other four treatments $(p<0.05)$. The hepatosomatic index (HSI) values significantly increased with $50 \%$ or higher substitution of $A$. pinnata as we observed in treatments $\mathrm{T}_{3}, \mathrm{~T}_{4}$, and $\mathrm{T}_{5}(p<0.05)$. The lowest HSI of fish $(1.32 \pm 0.04)$ was observed in $\mathrm{T}_{2}$, which was not statistically different from the fish in $\mathrm{T}_{1}(p>0.05)$.

The average protein efficiency ratio (PER) of fish was highest in $T_{1}$ followed by $T_{2}, T_{3}, T_{4}$, and $T_{5}$. There was no significant difference in PER between the fish fed treatments $T_{1}$ and $T_{2}(p>0.05)$. On the other hand, PER of fish in treatments $\mathrm{T}_{3}, \mathrm{~T}_{4}$, and $\mathrm{T}_{5}$ were significantly lower than that of treatments $\mathrm{T}_{1}$ and $\mathrm{T}_{2}(p<0.05)$. Similar to the other parameters, the lowest PER $(1.24 \pm 0.02)$ was observed in fish fed completely with fresh A. pinnata. 
Table 2. Growth performance of Thai silver barb Barbonymus gonionotus fed varying compositions of A. pinnata and commercial fish feed after 56 days.

\begin{tabular}{|c|c|c|c|c|c|}
\hline Treatments & $\mathbf{T}_{1}$ & $\mathbf{T}_{2}$ & $\mathrm{~T}_{3}$ & $\mathbf{T}_{4}$ & $\mathrm{~T}_{5}$ \\
\hline IAW (g) & $3.90 \pm 0.13$ & $3.90 \pm 0.11$ & $3.90 \pm 0.29$ & $3.90 \pm 0.09$ & $3.90 \pm 0.08$ \\
\hline FAW (g) & $30.93 \pm 0.4^{\mathrm{a}}$ & $30.68 \pm 0.4^{\mathrm{a}}$ & $24.55 \pm 0.45^{b}$ & $19.81 \pm 0.25^{c}$ & $15.20 \pm 0.39^{d}$ \\
\hline AWG (g) & $27.03 \pm 0.16^{\mathrm{a}}$ & $26.78 \pm 0.10^{a}$ & $20.65 \pm 0.19^{b}$ & $15.91 \pm 0.46^{\mathrm{c}}$ & $11.30 \pm 0.34^{\mathrm{d}}$ \\
\hline SGR $\left(\%\right.$ day $\left.^{-1}\right)$ & $3.70 \pm 0.14^{\mathrm{a}}$ & $3.68 \pm 0.16^{\mathrm{a}}$ & $3.28 \pm 0.11^{b}$ & $2.90 \pm 0.08^{c}$ & $2.43 \pm 0.18^{\mathrm{d}}$ \\
\hline $\mathrm{SR}(\%)$ & $99.33 \pm 1.15^{\mathrm{a}}$ & $98.67 \pm 1^{\mathrm{a}}$ & $99.33 \pm 0.58^{a}$ & $98 \pm 1^{\mathrm{a}}$ & $99.33 \pm 0.58^{a}$ \\
\hline NPR (ton ha ${ }^{-1}$ year $^{-1}$ ) & $9.88 \pm 0.65^{\mathrm{a}}$ & $9.73 \pm 0.40^{\mathrm{a}}$ & $7.84 \pm 0.21^{\mathrm{b}}$ & $6.24 \pm 0.36^{\mathrm{c}}$ & $4.85 \pm 0.79^{\mathrm{d}}$ \\
\hline $\mathrm{CF}$ & $2.35 \pm 0.035^{a}$ & $2.29 \pm 0.032^{\mathrm{a}}$ & $2.12 \pm 0.13^{\mathrm{a}}$ & $1.90 \pm 0.40^{\mathrm{a}}$ & $1.59 \pm 0.095^{b}$ \\
\hline HSI & $1.41 \pm 0.03^{\mathrm{a}}$ & $1.32 \pm 0.04^{\mathrm{a}}$ & $1.74 \pm 0.06^{\mathrm{b}}$ & $2.03 \pm 0.04^{\mathrm{c}}$ & $2.44 \pm 0.09^{\mathrm{d}}$ \\
\hline FCR & $0.88 \pm 0.09^{a}$ & $0.93 \pm 0.17^{\mathrm{a}}$ & $1.15 \pm 0.12^{b}$ & $1.66 \pm 0.15^{\mathrm{c}}$ & $2.64 \pm 0.06^{\mathrm{d}}$ \\
\hline PER & $2.98 \pm 0.03^{a}$ & $2.94 \pm 0.02^{\mathrm{a}}$ & $2.26 \pm 0.08^{b}$ & $1.75 \pm 0.07^{\mathrm{c}}$ & $1.24 \pm 0.02^{\mathrm{d}}$ \\
\hline
\end{tabular}

IAW = Initial average weight, FAW = Final average weight, AWG = Average weight gain, SGR = Specific growth rate, $\mathrm{SR}=$ Survival rate, $\mathrm{NPR}=$ Net production rate, $\mathrm{CF}=$ Condition factor, $\mathrm{HSI}=$ Hepatosomatic index, FCR= Feed conversion ratio, PER = Protein efficiency ratio. Means with different superscripts $(a, b, c$ and d) are significantly different $(p<0.05)$.

The survival rate of the fish was not affected significantly by the varying composition of feed. On the other hand, lower feed conversion ratios (FCR) were observed in $\mathrm{T}_{1}(0.89 \pm 0.09)$ and $\mathrm{T}_{2}(0.93 \pm 0.17)$. There was a significant difference of FCR between the fish fed with $25 \%\left(\mathrm{~T}_{2}\right)$ and $50 \%$ supplementation of $A$. pinnata protein $\left(\mathrm{T}_{3}\right)(p<0.05)$. FCR increased gradually among the fish fed in treatments $\mathrm{T}_{3}, \mathrm{~T}_{4}$, and $\mathrm{T}_{5}$ with greater proportions of the fresh plant. The highest FCR $(2.64 \pm 0.06)$ was noticed in fish fed at $T_{5}$. FCR gradually worsened with the increasing replacement level of fresh Azolla. Thus, more than $25 \%$ of supplementary A. pinnata protein significantly increased the FCR of the fish during the culture period. There was a negative correlation between the SGR and FCR of the fish, with $\mathrm{R}^{2}=0.987$ (Figure 1).

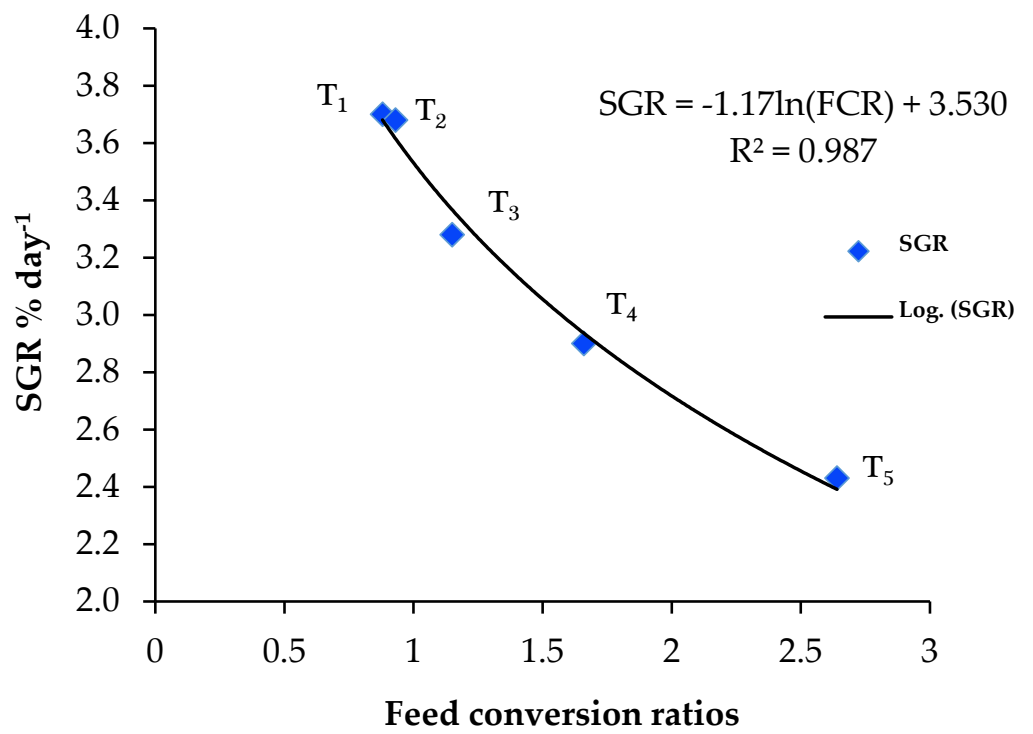

Figure 1. Relationship of SGR and FCR of Thai silver barb B. gonionotus fed different percentages of A. pinnata and commercial fish feed in five treatments after rearing for 56 days.

The proximate carcass compositions (\% in wet weight) of B. gonionotus reared in different feeding treatments are presented in Table 3. The highest carcass protein $(16.75 \pm 0.06 \%)$ content was observed in fish fed with $25 \%$ A. pinnata supplement $\left(\mathrm{T}_{2}\right)$ while there was no statistical difference among $\mathrm{T}_{1}-\mathrm{T}_{4}$ $(p>0.05)$. Replacement of more than $25 \%$ Azolla protein significantly reduced the lipid percentage and increased the moisture content of fish, as observed in the treatments $\mathrm{T}_{3}, \mathrm{~T}_{4}$, and $\mathrm{T}_{5}(p<0.05)$. In the case of $100 \%$ receiving $A$. pinnata, the fish had the lowest protein $(15.65 \pm 0.1 \%)$ and lipid values 
$(0.73 \pm 0.03 \%)$. However, the average carcass ash content of fish was not statistically affected by the feed $(p>0.05)$.

Table 3. Fish carcass proximate composition of Thai silver barb B. gonionotus (\% in wet weight) in different feeding treatments after 56 days.

\begin{tabular}{cccccc}
\hline Composition (\%) & $\mathbf{T}_{\mathbf{1}}$ & $\mathbf{T}_{\mathbf{2}}$ & $\mathbf{T}_{\mathbf{3}}$ & $\mathbf{T}_{\mathbf{4}}$ & $\mathbf{T}_{\mathbf{5}}$ \\
\hline Moisture & $74.25 \pm 1.11^{\mathrm{a}}$ & $74.44 \pm 0.83^{\mathrm{a}}$ & $76.31 \pm 0.39^{\mathrm{b}}$ & $77.57 \pm 1.34^{\mathrm{c}}$ & $80.88 \pm 0.19^{\mathrm{d}}$ \\
Protein & $16.56 \pm 0.09^{\mathrm{a}}$ & $16.75 \pm 0.06^{\mathrm{a}}$ & $16.26 \pm 0.07^{\mathrm{a}}$ & $16.37 \pm 0.11^{\mathrm{a}}$ & $15.65 \pm 0.1^{\mathrm{b}}$ \\
Lipid & $5.34 \pm 0.52^{\mathrm{a}}$ & $5.02 \pm 0.15^{\mathrm{a}}$ & $3.86 \pm 0.14^{\mathrm{b}}$ & $2.19 \pm 0.04^{\mathrm{c}}$ & $0.73 \pm 0.03^{\mathrm{d}}$ \\
Ash & $3.00 \pm 0.09^{\mathrm{a}}$ & $3.00 \pm 0.24^{\mathrm{a}}$ & $2.81 \pm 0.12^{\mathrm{a}}$ & $3.00 \pm 0.11^{\mathrm{a}}$ & $2.74 \pm 0.20^{\mathrm{a}}$ \\
\hline
\end{tabular}

Values represent the average composition \pm SD of the fish carcass $(n=3)$. Means with different superscripts $(\mathrm{a}, \mathrm{b}, \mathrm{c}$ and $\mathrm{d})$ are significantly different $(p<0.05)$.

The costs and returns by providing fresh A. pinnata as a replacement of CFF in different treatments found in this study are depicted in Figure 2. The use of plant protein significantly affected the cost, return, and net profit rate in Thai silver barb production. A significant reduction of feed cost and, therefore, the total cost was seen in the treatments as a greater percentage of CFF was replaced with $A$. pinnata. The total return calculated from evaluating the market price of fish was $2767.35 \pm 2.66 \mathrm{USD} \mathrm{ha}^{-1} 56$ days $^{-1}$ and $2726.75 \pm 3.45 \mathrm{USD} \mathrm{ha}^{-1} 56$ days $^{-1}$ fish reared in $\mathrm{T}_{1}$ and $\mathrm{T}_{2}$, respectively, which was not significantly varied $(p>0.05)$. However, a significantly higher net profit of $431.49 \pm 0.58 \mathrm{USD} \mathrm{ha}^{-1} 56$ days $^{-1}$ is calculated for fish fed with $25 \%$ A. pinnata $\left(\mathrm{T}_{2}\right)$ compared to the profit of $214.33 \pm 0.18$ USD for the fish fed totally with CFF $\left(\mathrm{T}_{1}\right)$ for 56 days $(p<0.05)$. The net profit lowered gradually from the feeding treatments $T_{3}$ to $T_{5}$. The lowest net profit was calculated in fish produced with sole Azolla feed at $\mathrm{T}_{5}(46.97 \pm 1.89 \mathrm{USD})$.

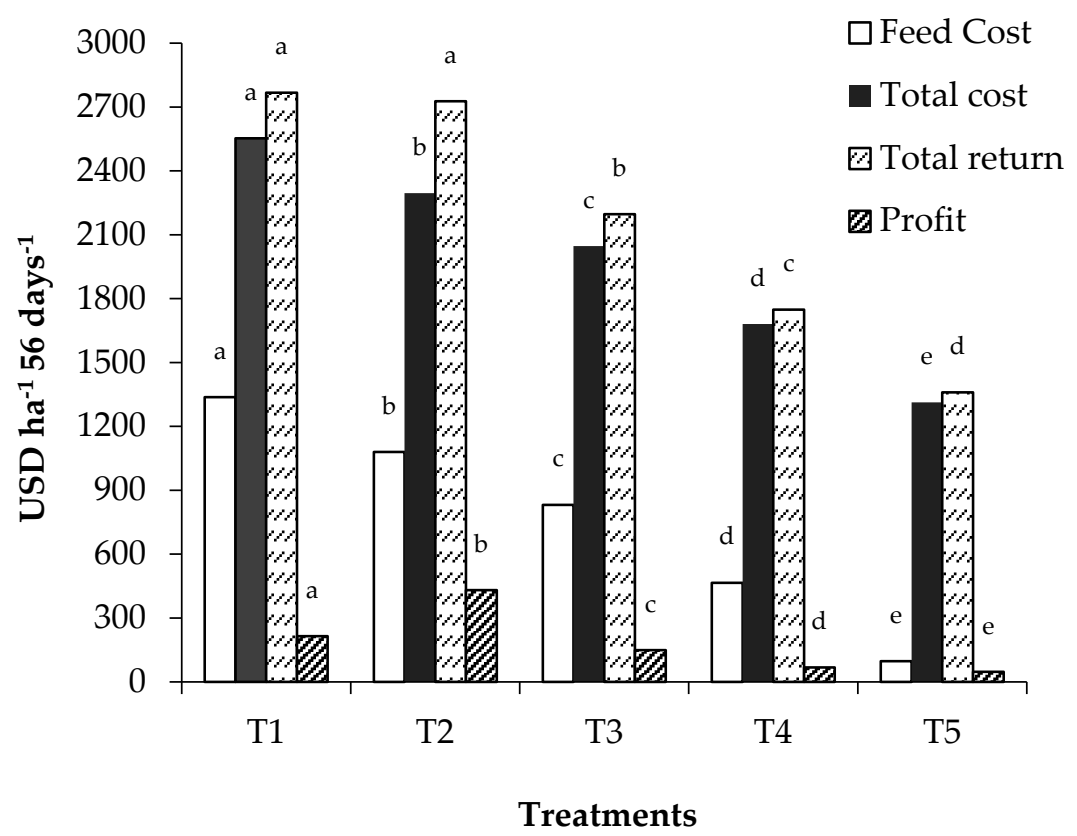

Figure 2. Cost and return (USD ha ${ }^{-1} 56$ days $^{-1}$ ) from Thai silver barb B. gonionotus produced in five treatments fed varying proportion of $A$. pinnata and commercial fish feed for 56 days. Means with different superscripts (a, b, c, d and e) are significantly different $(p<0.05)$.

\section{Discussion}

The AWG and SGR of the fish found in this study fed with different inclusion levels of fresh A. pinnata indicate the acceptable replacement level of CFF with the plant protein. More than $25 \%$ 
supplementary of $A$. pinnata in the diet significantly reduced the growth rate of Thai silver barb. In the treatment $T_{5}$, SGR and NPR were lowest probably due to the use of only A. pinnata or plant diets, which resulted in very poor growth. The results are comparable to those reported in several studies with the same purpose of replacing fish meal by the plant protein in Nile tilapia feeding [21,22]. Similarly, Sudaryono [23] recorded that substitution of $0 \%, 25 \%, 50 \%, 75 \%$, and $100 \%$ of soybean meal with A. pinnata lowered the growth of black tiger shrimp (Penaeus monodon). The SGR and NPR of fish were higher in this study for up to $75 \%$ Azolla substitution compared to the reports by Kohinoor et al. [24] and Shah et al. [25] who used duckweed and rice bran, respectively, as low-cost supplementary feed.

The high rate of plant protein in the treatments $T_{3}$ to $T_{5}$ could be responsible for the poor growth rate of $B$. gonionotus in this study. The lower growth performance of the fish fed with higher proportions of the fresh $A$. pinnata-based diet could be because of the difficulty in digesting raw plant ingredients. It could be anticipated that $A$. pinnata being freshly provided as feed could have been poorly utilized. The plants contain high amounts of indigestible fiber, carbohydrates, and some anti-nutritional factors, and are often insufficient in certain essential amino acids methionine and lysine, compared to animal protein, which causes adverse effects on feed absorption, digestion, and utilization and could have lowered the growth performance when included at a high-level [26]. Azolla africana has been found to contain a small fraction of some anti-nutritional factors, such as cyanide, tannin, and phytic acid [27]. Micha et al. [28] found the SGR of tilapia fish decreased gradually with increasing levels of protein from fresh Azolla microphylla. The reduced growth performance can be explained by impaired protein, amino acid, lipid, and energy digestibility of the fresh plant. The nutritional quality of fresh A. pinnata could be improved by chemical and mechanical processing, which can concentrate the protein content and eliminate the effect of anti-nutrients, but will increase the cost of feed.

We noted the decrease of SGR and the increase of FCR as the inclusion of supplementary Azolla rose, while the significant effect of that was seen in the case of more than $25 \%$ replacement. Therefore, it is evident that $25 \%$ replacement of CFF with the plant does not have a significant effect on the growth performance and nutrient utilization of $B$. gonionotus. This finding suggests that a higher quantity of plant protein was required to produce $1 \mathrm{~g}$ of flesh of $B$. gonionotus compared to CFF. This could be due to either poor absorption of the protein of supplementary A. pinnata by the fish or poor protein quality (amino acid composition). In a previous study, Abou et al. [29] noted that FCR values rose from $0 \%$ to $50 \%$ substitution of Azolla filiculoides for Nile tilapia (Oreochromis niloticus L.). In contrast, Badwy et al. [30] reported that up to 50\% replacement of fishmeal with single-celled algae Chlorella spp. and Scenedesmus spp. had higher growth performance, protein productive value and lower FCR of Nile tilapia, whereas 75\% algae content showed significantly lower performance. Lower PER or protein utilization of the fish was found when the more CFF was replaced with A. pinnata. Similarly, Sudaryono [23] noted that A. pinnata inclusion in the diet of black tiger shrimp (P. monodon) reduced PER values. Additionally, Abou et al. [29] recorded that PER progressively reduced from $0 \%$ to $50 \%$ substitution of fish meal with Azolla meal in Nile tilapia feeding.

Twenty-five percent inclusion of Azolla in $\mathrm{T}_{2}$ could utilize carbohydrate properly and comprise the lowest HSI. High-energy inclusion as a form of carbohydrate in the body of fish usually follows an increased HSI. The increase in HSI value as an increment of dietary carbohydrate inclusion is in line with previous reports in different fish [31-33]. On the other hand, more than $25 \%$ of A. pinnata significantly reduced the CF of fish. The CF is an indication of the nutritional status of fish and is based on the hypothesis that too low a CF can be a sign of poor well-being or undernourishment, while too high a value can be a sign of overweight and fat liver [34-36]. From the proximate analysis, it is observed that the composition of fish carcasses, especially lipids, were degraded with an increment of A. pinnata protein. The lowering of lipid content was significant when more than $25 \%$ CFF protein was replaced with the plant protein.

Therefore, $25 \%$ of CFF can be replaced with fresh $A$. pinnata without compromising average $C F$ and HSI. B. gonionotus is an omnivorous species fed with macrophyte, organic materials, phytoplankton, etc., 
whose gut is found to be 2.9 times longer at a body length of $55-80 \mathrm{~mm}$ (standard length) [37]. Due to their potential utilization of plants, the fish grew comparatively well in diets containing $25 \%$ A. pinnata. The higher plant treatments $\left(\mathrm{T}_{3}-\mathrm{T}_{5}\right)$ showed a reduced performance basically in all the parameters, but the reasons for this can only be speculated. The poor performance of fish receiving more Azolla protein could be due to a reduced digestion or uptake of nutrients, a reduced availability of nutrients, or a lower protein quality, which starts to count when higher amounts were fed, or an increasing amount of anti-nutritional factors.

Due to the use of unprocessed Azolla, and its lower production and processing cost, the prices of feed were gradually decreased by increasing supplementary A. pinnata meal levels from 1337.61 to 97.58 USD. Lowering the cost of feed reflects significantly high profit margins in fish fed at $\mathrm{T}_{2}$ compared to the control CFF diet $\left(\mathrm{T}_{1}\right)$. Feed cost is often estimated to be approximately half of the total cost of production of the fish. The cost of CFF is exclusively higher than $A$. pinnata due to containing high-cost feed ingredients. Here, the total cost of each treatment was calculated by including several cost factors such as: fish fries, lime, feed, and maintenance costs. The feed cost was only variable while others expenditures were the same for all the treatments. However, in spite of the indicative reduction of feed cost net profits in treatment $T_{3}, T_{4}$ and $T_{5}$ were significantly lower compared to $T_{1}$ and $T_{2}$ due to the lower fish biomass obtained by poor utilization of the plant. Similar results were reported for corn gluten meal [38] and cotton seed meal [39] in tilapia diets. The significantly higher profit margin and lack of significant impact on growth at a $25 \%$ inclusion rate of $A$. pinnata suggests that feeding with a certain proportion of fresh Azolla might be beneficial for Thai silver barb.

\section{Materials and Methods}

\subsection{Cultivation of A. pinnata}

A. pinnata was collected from the Azolla-rice culture field of the Bangladesh Rice Research Institute, Gazipur, Bangladesh. Then, it was grown in 1- $\mathrm{m}^{2}$ earthen pits with a $10 \mathrm{~cm}$ water depth supplied with organic: cow dung ( $\left.1 \mathrm{~kg} \mathrm{week}^{-1} \mathrm{~m}^{-2}\right)$ and inorganic fertilizers: urea (46\% nitrogen) and triple super phosphate $(45 \% \mathrm{P})\left(100 \mathrm{~g}_{\text {week }}{ }^{-1} \mathrm{~m}^{-2}\right)$. A partial shed was put above the pits to prevent direct sunlight. A. pinnata was harvested with a scoop net, then thoroughly washed with fresh water to remove dirt and debris. After cleaning, the plants were slightly minced by hand to provide to the juvenile B. gonionotus the fresh material. Cultivation of $A$. pinnata continued over the whole experimental period to supply fresh A. pinnata to the fish.

\subsection{Nutrient Composition Analysis of Feed}

The commercial feed was composed of maize, rice polish, fish meal, animal protein (blood meal, feather meal), soybean meal, and vitamin and mineral premix. Proximate and some mineral composition of the floating CFF and A. pinnata were performed following Association of Official Analytical Chemists (AOAC) [40] standard protocol to evaluate the nutritive value of the plant. Moisture content was determined by placing an accurately-weighed amount $(1 \mathrm{~g})$ of ground sample in a pre-weighed porcelain crucible in a thermostat oven at $105^{\circ} \mathrm{C}$ for $24 \mathrm{~h}$. The loss of weight was calculated as a percent of moisture content. Crude protein was determined indirectly by measuring total nitrogen content by the standard Micro-Kjeldahl method. Known quantities of sample, catalyst mixture $(1.0 \mathrm{~g})$, and concentrated $\mathrm{H}_{2} \mathrm{SO}_{4}(5 \mathrm{~mL})$ were taken in a Kjeldahl tube (model DK20, VELP Scientifica, Milano, Italy) for $90 \mathrm{~min}$. The digested sample was then distilled and titrated simultaneously with an automatic distillation and titration unit (model UDK152, VELP Scintifica, Milano, Italy). Crude lipid content was determined by extracting a weighed sample in diethyl ether for $6 \mathrm{~h}$ in a Soxhlet apparatus. Ash content was determined by igniting the sample in a muffle furnace at $550{ }^{\circ} \mathrm{C}$ for $6 \mathrm{~h}$. 
The actual amount of the CFF to be replaced with the fresh plant was calculated based on the protein percentage. Therefore, the treatments' feed percentages were designed so that the plant protein fulfills the protein percentage of the CFF.

\subsection{Feeding Experiment}

For the feeding experiment, fifteen $1-\mathrm{m}^{3}$ cages were constructed with iron rods and nylon net and floated in the pond affixed to a certain platform. The cages were randomly distributed over two sides of a fixed platform at the experimental pond of Bangabandhu Sheikh Mujibur Rahman Agricultural University, Bangladesh. The juveniles of Thai silver barb were collected from the nearest hatchery and acclimatized for 7 days into the nursery prior to moving to the experimental cages. Five treatments ( $\mathrm{T}_{1}$ to $\mathrm{T}_{5}$ ) were designed to vary in CFF substitution rate of $0 \%, 25 \%, 50 \%, 75 \%$, and $100 \%$ with A. pinnata. Twenty fish with an approximate initial size of $3.90 \mathrm{~g}$ were transferred into the cages in five separate treatments with three replications. The fish were fed with floating commercial pellet feed (Narish Feed Ltd., Dhaka, Bangladesh) and fresh A. pinnata for 56 days according to the experimental design of the respective treatments (Table 4).

Table 4. Experimental design and feeding dose (at initial level) at different treatments.

\begin{tabular}{ccccccc}
\hline \multirow{2}{*}{ Treatments } & \multicolumn{2}{c}{ Protein \% (Dry Matter) } & \multicolumn{2}{c}{ Protein (g/day) } & \multicolumn{2}{c}{ Feed Quantity (g in Wet Weight/day) } \\
\cline { 2 - 7 } & CFF & A. pinnata & CFF & A.pinnata & CFF & A. pinnata \\
\hline $\mathrm{T}_{1}$ (Control) & 100 & 0 & 5.46 & 0 & 17.63 & 0 \\
$\mathrm{~T}_{2}$ & 75 & 25 & 4.10 & 1.36 & 13.23 & 15.27 \\
$\mathrm{~T}_{3}$ & 50 & 50 & 2.73 & 2.73 & 8.81 & 30.64 \\
$\mathrm{~T}_{4}$ & 25 & 75 & 1.36 & 4.10 & 4.40 & 46.03 \\
$\mathrm{~T}_{5}$ & 0 & 100 & 0 & 5.46 & 0 & 61.27 \\
\hline
\end{tabular}

A fine mesh size net was encircled at the certain point above part of the cage to avoid wastage of feed. The feeding rate and frequency were set according to Islam et al. [41]. Feeding was done by hand in the morning hours between 8:00 and 9:00 a.m. and in the evening between 5:00 and 6:00 p.m. The Azolla feed portions were provided about $10 \mathrm{~min}$ before than the CFF to allow fish to consume some of that.

The feed and protein amount served at each treatment which is mentioned in Table 4 was continued until the fish reached $5 \mathrm{~g}$. Fish were weighed every fortnight and the feeding rate was adjusted according to their body weight (Table 5). The project was approved on 30 November 2014 by the Research Management Committee (RMC) of the Bangabandhu Sheikh Mujibur Rahman Agricultural University, Gazipur, Bangladesh (Project ID: BSMRAU/AQC/RMC/2014/2).

Table 5. Feed application rate according to the weight of fish.

\begin{tabular}{cc}
\hline Average Fish Weight (g) & Daily Ratio (\% of Body Weight) \\
\hline $1-5$ & 10 \\
$5-10$ & 5 \\
$10-30$ & 4 \\
\hline
\end{tabular}

\subsection{Fish Rearing and Management}

The experimental cages received no aeration or other inputs except feed. The physicochemical parameters of water such as temperature, $\mathrm{DO}, \mathrm{pH}$, ammonia, and phosphate-phosphorus concentration were monitored to ensure the quality of water within the standard limits for B. gonionotus. The temperature was recorded using a thermometer (digi-thermo WT-2, King Till, Suzhou, China). Dissolved oxygen and $\mathrm{pH}$ were measured using a Lutron DO-5509 (Lutron Electronics Co., Inc., Irvine, CA, USA) and pH meter (Eco Testr pH 2, Oakton, Vernon Hills, IL, USA). Ammonia was calculated every week with HANNA instrument test kits. 


\subsection{Growth and Nutritional Parameters Analysis}

Growth parameters (weight and length) and conditions of fish were recorded every fortnight and at the end of the experiment per replicates of the five treatment diets. Fish were starved for about $12 \mathrm{~h}$ and weighed separately with an electric balance. Five animals were collected from each cage at the end of the experiment to perform proximate composition (moisture, crude protein, crude lipid, and ash) and HSI. The fish were dissected and proximate composition of the fish carcass was measured according to standard procedures [40]. In addition, HSI was recorded according to Ighwela et al. [42].

\subsection{Calculation and Statistical Analysis}

At the end of the experiment, yearly NPR was estimated and profit rate for the duration of experimental period was calculated individually for each treatment.

The following calculations have been conducted:

Weight gain $(\mathrm{g})=$ Mean final weight $(\mathrm{g})-$ Mean initial weight $(\mathrm{g})$

Specific growth rate (SGR) $\left(\%\right.$ day $\left.^{-1}\right)=($ Ln final weight $(\mathrm{g})-$ Ln initial weight $(\mathrm{g}) /($ Period in days $) \times 100$

Feed conversion ratio $(\mathrm{FCR})=$ Feed intake $(\mathrm{g}) /$ Live weight gain $(\mathrm{g})$

Condition Factor $(\mathrm{K})=$ Fish weight $(\mathrm{g}) /(\text { Fish length })^{3}(\mathrm{~cm}) \times 100$

Hepatosomatic index $(\mathrm{HSI})=$ Liver weight $(\mathrm{g}) /$ Body weight $(\mathrm{g}) \times 100$

Protein efficiency ratio $($ PER) $=$ Weight gain $(\mathrm{g}) /$ Protein intake $(\mathrm{g})$

Survival rate $\%=($ No. of harvested fish $/$ No. of initial stocked fish $) \times 100$

Net fish production $($ ton $/$ ha $/$ year $)=($ Net weight of fish $(\mathrm{kg}) / \mathrm{ha} / \mathrm{month} \times 12) / 1000$

Total production $=$ No. of harvested fish $\times$ Average harvested weight

$$
\text { Net Profit }=\text { Total income }- \text { Total cost }
$$

The data were analyzed statistically by one-way ANOVA and an $\mathrm{LSD}_{0.05}$ test was applied in the case of significant differences. Statistical software Statistix 10 (Analytical Software, Tallahassee, FL, USA) was used for all the analyses.

\section{Conclusions}

Fresh A. pinnata could be an attractive ingredient to consider for the formulation of a low-cost diet. A. pinnata was utilized well by the B. gonionotus at a $25 \%$ substitution of CFF. The acceptance of the diet formulae for Thai silver barb in $\mathrm{T}_{2}(25 \%$ A. pinnata: $75 \% \mathrm{CFF})$ and its significant higher profit rate, suggest it is an exceptionally cheap way of formulating feed for B. gonionotus. Consequently, A. pinnata is beneficial in the formulation of fish feed while discouraging a total dependency on exclusively expensive CFF. However, increasing ratios of plants above $25 \%$ in diets significantly affected the production performances of the fish. Therefore, the study suggests that a one-fourth proportion of CFF replacement with fresh $A$. pinnata could be a sustainable alternative option to save the cost of Thai silver barb production and offer high-profit margins.

Acknowledgments: This work was supported by the project "Development of a low-cost diet for Thai silver barb Barbonymus gonionotus (Bleeker, 1850) by substituting commercial feed with aquatic fern, Azolla pinnata". The authors thank the Research Management Committee (RMC) of Bangabandhu Sheikh Mujibur Rahman Agricultural University and University Grant Commission (UGC) of Bangladesh for the grant.

Author Contributions: Mousumi Das was the principal investigator and designed the experiments. Ferdous Ibn Rahim performed the experiments and analyses with the assistance of Mousumi Das. Md. Amzad Hossain was the co-investigator and supervised the experiments. All the authors have contributed in the writing and editing of the manuscript.

Conflicts of Interest: The author declares no conflict of interest. 


\section{References}

1. Narejo, N.T.; Dars, B.A.; Achakzai, G.D. Preparation of low-cost fish feed for the culture of Labeo rohita (hamilton) in glass aquaria. Sindh Univ. Res. J. (Sci. Ser.) 2010, 42, 7-10.

2. Hardy, R.W. Alternate protein sources for salmon and trout diets. Anim. Feed Sci. Technol. 1996, 59, 71-80. [CrossRef]

3. Hardy, R.W. Utilization of plant proteins in fish diets: Effects of global demand and supplies of fishmeal. Aquac. Res. 2010, 41, 770-776. [CrossRef]

4. Kaushik, S.J.; Covès, D.; Dutto, G.; Blanc, D. Almost total replacement of fish meal by plant protein sources in the diet of a marine teleost, the European seabass, Dicentrarchus labrax. Aquaculture 2004, 230, 391-404. [CrossRef]

5. Goswami, U.; Goswami, S.C. Formulation of cheaper artificial feeds for shrimp culture: Preliminary biochemical, physical and biological evaluation. Aquaculture 1979, 16, 309-317. [CrossRef]

6. Law, A.T. Digestibility of low-cost ingredients in pelleted feed by grass carp (Ctenopharyngodon idella C. et V.). Aquaculture 1986, 51, 97-103. [CrossRef]

7. Wahab, M.A.; Azim, M.E.; Mahmud, A.A.; Kohinoor, A.H.M.; Haque, M.M. Optimisation of stocking density of Thai silver barb (Barbodes gonionotus Bleeker) in the duckweed-fed four species polyculture system. Bangladesh J. Fish. Res. 2001, 5, 13-21.

8. Mahean Haque, S.; Wahab, M.A.; Wahid, M.I.; Haq, M.S. Impacts of Thai silver barb (Puntius gonionotus Bleeker) inclusion in the polyculture of carps. Bangladesh J. Fish. Res. 1998, 2, 15-22.

9. Rothuis, A.J.; Duong, L.T.; Richter, C.J.J.; Ollevier, F. Polyculture of silver barb, Puntius gonionotus (Bleeker), Nile tilapia, Oreochromis niloticus (L.), and common carp, Cyprinus carpio L. in Vietnamese ricefields: Feeding ecology and impact on rice and ricefield environment. Aquac. Res. 1998, 29, 649-660. [CrossRef]

10. Wahab, M.A.; Ahmed, Z.F.; Islam, M.A.; Haq, M.S.; Rahmatullah, S.M. Effects of introduction of common carp, Cyprinus carpio (L.), on the pond ecology and growth of fish in polyculture. Aquac. Res. 1995, 26, 619-628. [CrossRef]

11. Prabina, B.J.; Kumar, K. Dried Azolla as a nutritionally rich cost effective and immuno-modulatory feed supplement for broilers. Asian J. Anim. Sci. 2010, 5, 20-22.

12. Maity, J.; Patra, B.C. Effect of replacement of fishmeal by Azolla leaf meal on growth, food utilization, pancreatic protease activity and RNA/DNA ratio in the fingerlings of Labeo rohita (Ham.). Can. J. Pure Appl. Sci. 2008, 2, 323-333.

13. Cherryl, D.M.; Prasad, R.M.V.; Rao, J.S.; Jayalaxmi, P.; Kumar, D.S. A study on the nutritive value of Azolla pinnata. Livest. Res. Int. 2014, 2, 13-15.

14. Basak, B.; Pramanik, M.A.H.; Rahman, M.S.; Tarafdar, S.U.; Roy, B.C. Azolla (Azolla pinnata) as a Feed Ingredient in Broiler Ration. Int. J. Poult. Sci. 2002, 1, 29-34.

15. Anitha, K.C.; Rajeshwari, Y.B.; Prasanna, S.B.; Shilpa, S.J. Nutritive evaluation of Azolla as livestock feed. J. Exp. Biol. Agric. Sci. 2016, 4, 670-674.

16. Pillai, P.K.; Premalatha, S.; Rajamony, S. AZOLLA-A sustainable feed substitute for livestock. LEISA India 2002, 4, 15-17.

17. Cagauan, A.G.; Branckaert, R.D.; Van Hove, C. Integrating fish and azolla into rice-duck farming in Asia. Naga ICLARM Q. 2000, 23, 4-10.

18. Cagauan, A.G.; Pullin, R.S.V. Azolla in aquaculture: Past, present and future. In Recent Advances in Aquaculture; Muir, J., Roberts, R.J., Eds.; Blackwell Science: Oxford, UK, 1994; pp. 104-130.

19. Mohanty, S.N.; Dash, S.P. Evaluation of Azolla caroliniana for inclusion in carp diet. J. Aquac. Trop. 1995, 10, 343-354.

20. Fiogbé, E.D.; Micha, J.C.; Van Hove, C. Use of a natural aquatic fern, Azolla microphylla, as a main component in food for the omnivorous-phytoplanktonophagous tilapia, Oreochromis niloticus L. J. Appl. Ichthyol. 2004, 20, 517-520. [CrossRef]

21. Hossain, M.A.; Focken, U.; Becker, K. Nutritional evaluation of dhaincha (Sesbania aculeata) seeds as dietary protein source for tilapia Oreochromis niloticus. Aquac. Res. 2002, 33, 653-662. [CrossRef]

22. Fasakin, E.A.; Balogun, A.M.; Fagbenro, O.A. Evaluation of Sun-Dried Water Fern, Azolla africana and Duckweed, Spirodela polyrrhiza in Practical Diets for Nile Tilapia, Oreochromis niloticus Fingerlings. J. Appl. Aquac. 2001, 11, 83-92. [CrossRef] 
23. Sudaryono, A. Use of Azolla (Azolla pinnata) meal as a substitute for defatted soybean meal in diets of juvenile black tiger shrimp (Penaeus monodon). J. Coast. Dev. 2006, 9, 145-154.

24. Kohinoor, A.H.M.; Islam, M.S.; Begum, N.; Hussain, M.G. Production of Thai sharpunti (Puntius gonionotus Bleeker) in polyculture with carps using low-cost feed. Bangladesh J. Fish. Res. 1999, 3, 157-164.

25. Azad Shah, A.K.M.; Hossain, M.A.; Afsana, K. Effect of different rice brans on the growth of Thai silver barb (Puntius gonionotus Bleeker) in seasonal ponds. Bangladesh J. Fish. Res. 1998, 2, 159-169.

26. Krogdahl, Å.; Penn, M.; Thorsen, J.; Refstie, S.; Bakke, A.M. Important antinutrients in plant feedstuffs for aquaculture: An update on recent findings regarding responses in salmonids. Aquac. Res. 2010, 41, 333-344. [CrossRef]

27. Fasakin, E.A. Nutrient quality of leaf protein concentrates produced from water fern (Azolla africana Desv) and duckweed (Spirodela polyrrhiza L. Schleiden). Biores. Technol. 1999, 69, 185-187. [CrossRef]

28. Micha, J.C.; Antoine, T.; Wery, P.; Van Hove, C. Growth, ingestion capacity, comparative appetency and biochemical composition of Oreochromis niloticus and Tilapia rendalli fed with Azolla. In Proceedings of the Second International Symposium on Tilapia in Aquaculture, Department of Fisheries, Bangkok, Thailand, 16-20 March 1987; Pullin, R.S.V., Bhukaswan, T., Tonguthai, K., Maclean, J.L., Eds.; International Centre for Living Aquatic Resource Management: Manila, Philippines, 1998.

29. Abou, Y.; Fiogbé, E.D.; Beckers, Y.; Micha, J.C. Approximate compositional values and tissue fatty acid profiles of Nile Tilapia (Oreochromis niloticus L.) fed Azolla-diets in earthen ponds. Food Nutr. Sci. 2011, 2, 964-973. [CrossRef]

30. Badwy, T.M.; Ibrahim, E.M.; Zeinhom, M.M. Partial replacement of fish meal with dried microalga (Chlorella spp and Scendesmus spp.) in Nile tilapia (Oreochromis niloticus) diets. In Proceedings of the Eighth International Symposium on Tilapia in Aquaculture, Cairo, Egypt, 12-14 October 2008.

31. Ahmad, M.; Qureshi, T.A.; Singh, A.B.; Manohar, S.; Borana, K.; Chalko, S.R. Effect of dietary protein, lipid and carbohydrate contents on the carcass composition of Cyprinus carpio communis fingerlings. Int. J. Fish. Aquac. 2012, 4, 30-40.

32. Ali, M.Z.; Jauncey, K. Optimal dietary carbohydrate to lipid ratio in African catfish Clarias gariepinus (Burchell 1822). Aquac. Int. 2004, 12, 169-180. [CrossRef]

33. Enyidi, U.D.; Pirhonen, J.; Kettunen, J.; Vielma, J. Effect of feed protein:lipid ratio on growth parameters of African Catfish Clarias gariepinus after fish meal substitution in the diet with bambaranut (Voandzeia subterranea) meal and soybean (Glycine max) meal. Fishes 2017, 2, 1. [CrossRef]

34. Bagenal, T.B.; Tesch, A.T. Conditions and Growth Patterns in Fresh Water Habitats; Blackwell Scientific Publications: Oxford, UK, 1978.

35. Fagade, S.O. Observation of the biology of two species of Tilapia from the Lagos lagoon Nigeria. Bull. Inst. Fond. Afr. Noire (Ser. A) 1979, 41, 627-653.

36. Ayoade, A.A. Length-weight relationship and diet of African carp Labeo ogunensis (Boulenger, 1910) in Asejire Lake Southwestern Nigeria. J. Fish. Aquat. Sci. 2011, 6, 472-478. [CrossRef]

37. Mostakim, M.; Islam, M.S.; Rahman, M.K.; Rahmatullah, S.M. Size related feeding patterns and electivity indices of silver barb (Barbodes gonionotus Bleeker) from a pond, Bangladesh. Bangladesh J. Fish. Res. 2001, 5, 105-114.

38. Wu, Y.V.; Rosati, R.; Sessa, D.J.; Brown, P. Utilization of corn gluten feed by Nile Tilapia. Prog. Fish-Cult. 1995, 57, 305-309. [CrossRef]

39. El-Sayed, A.F.M. Long-term evaluation of cotton seed meal as a protein source for Nile tilapia, Oreochromis niloticus (Linn.). Aquaculture 1990, 84, 315-320. [CrossRef]

40. Cunniff, P. Official Methods of Analysis of AOAC International; Association of Official Analytical Chemists: Washington, DC, USA, 1995; ISBN 978-0-935584-54-7.

41. Islam, M.M.; Rahman, M.H.; Rahman, M.M. Training Manual on Improved Carp/Carp-Shing Poly Culture in Pond and Dyke Cropping; Collis, W.J., Hossain, M.M., Miah, M.M.A., Sarker, A.K., Islam, M.M., Roy, S., Saha, G.C., Jahura, I., Eds.; Director World Fish Center: Dhaka, Bangladesh, 2011.

42. Ighwela, K.A.; Ahmad, A.B.; Abol-Munafi, A.B. The selection of viscerosomatic and hepatosomatic indices for the measurement and analysis of Oreochromis niloticus condition fed with varying dietary maltose levels. Int. J. Fauna Biol. Stud. 2014, 1, 18-20. 